Check for updates

Cite this: RSC Adv., 2020, 10, 6200

Received 20th October 2019 Accepted 9th January 2020

DOI: $10.1039 / c 9 r a 08575 k$

rsc.li/rsc-advances

\section{Biofunctionalization of zirconia with cell-adhesion peptides via polydopamine crosslinking for soft tissue engineering: effects on the biological behaviors of human gingival fibroblasts and oral bacteria†}

\author{
Zhen Yang, $t^{a}$ Mingyue Liu, $t^{\mathrm{b}}$ Yang Yang, ${ }^{\mathrm{a}}$ Miao Zheng, ${ }^{\mathrm{c}}$ Yang Yang, (D) ${ }^{a}$ Xiaoqiang Liu ${ }^{a}$ \\ and Jianguo Tan (iD)*a
}

Rapid soft tissue integration is essential for long-term dental implant success. Zirconia is increasingly used as an abutment material owing to its excellent aesthetic properties and biocompatibility; however, it is bioinert, and tissue integration is poor. We developed a feasible surface modification method, exploiting the reactivity of polydopamine (PDA) films to immobilize cell-adhesion peptides (Arg-Gly-Asp, RGD) onto zirconia abutment surfaces. Further, we evaluated the effect thereof on human gingival fibroblast (HGF) behavior and oral bacterial adhesion, which influence the peri-implant soft tissue seal. HGF responses to linear KGGRGDSP and cyclic RGDfK sequences were compared. PDA deposition and covalent coupling of RGD were verified by X-ray photoelectron spectroscopy and fluorescence microscopy. The biological behaviors of HGFs on the modified zirconia; i.e., adhesion, spreading, proliferation, gene and protein expression, were elucidated. Biofunctionalization of zirconia with the adhesion peptides significantly enhanced the biological activities of HGFs. Cyclic RGD induced slightly improved cell attachment, spreading, and proliferation, but similar cell differentiation when compared to linear RGD peptides. To assess their antimicrobial properties, the different substrates were exposed to cultures of the early colonizer Streptococcus mutans or the periodontal pathogen Porphyromonas gingivalis, and bacterial adhesion was evaluated by scanning electron microscopy and live/dead staining. PDA and PDA-RGD coatings decreased zirconia surface colonization by both bacterial species to similar extents. Thus, PDA-RGD-functionalized zirconia modulates specific HGF responses, while maintaining the antimicrobial activity of the PDA coating. The selective bio-interaction pattern of this surface modification holds great promise for improving soft-tissue integration around zirconia abutments in clinical applications.

\section{Introduction}

Dental implants are extensively used to replace missing teeth. ${ }^{\mathbf{1}}$ Long-term implant stability relies not only on successful osseointegration but also on effective integration of the implant

\footnotetext{
${ }^{a}$ Department of Prosthodontics, Peking University School and Hospital of Stomatology, National Clinical Research Center for Oral Diseases, National Engineering Laboratory for Digital and Material Technology of Stomatology, Beijing Key Laboratory of Digital Stomatology, Beijing, 100081, P. R. China. E-mail: tanwume@vip.sina.com; Fax: +8610-62173402; Tel: $+86-10-82195364$

${ }^{b}$ First Clinical Division, Peking University School and Hospital of Stomatology, Beijing, 100034, P. R. China

'Department of Stomatology, Peking University Third Hospital, Beijing, 100191, P. R. China

$\dagger$ Electronic supplementary information (ESI) available. See DOI: $10.1039 / \mathrm{c} 9 \mathrm{ra} 08575 \mathrm{k}$

\$ These authors contributed equally to this work.
}

surface with the surrounding soft tissue. The soft tissue seal around the implant abutment acts as a barrier between the oral environment and the alveolar bone, thus preventing bacterial penetration, protecting the underlying bone, and maintaining the normal shape of the gingiva. ${ }^{2}$ However, soft tissue around the implant abutment is different from that around natural teeth; it has fewer human gingival fibroblasts (HGFs), lacks vascularity, and peripheral fibers are arranged in parallel, leading to relatively poor bacterial resistance and ultimately influencing restoration longevity. ${ }^{3}$ This limitation can be overcome, in part, by modifying the implant surfaces to allow better adhesion to the soft tissue. Accordingly, the improvement in soft tissue compatibility via implant surface modification has become a research focus.

The soft tissue seal surrounding dental implants can be affected by microbial infection. Early infections usually originate from microbial contamination during and immediately 
after surgery. Contaminating pathogens, including early colonizers such as streptococci, and host cells such as fibroblasts compete to cover the implant, which was described as "race for the surface" by Gristina et al. ${ }^{4}$ If bacteria occupy the surface before host cells arrive, a plaque biofilm will be formed that protects the bacteria from being replaced by tissue cells, thus influencing soft tissue barrier formation. Late infections (periimplantitis/peri-implant mucositis) present a different form of race for the surface, i.e., peri-implantitis pathogens displace periodontal ligament fibroblasts from the implant surface, leading to adjacent tissue damage or even implant failure. ${ }^{5}$ Indeed, peri-implant lesions are among the most frequent and severe implant complications, and are difficult to treat. ${ }^{6}$ In this regard, early formation of an effective and durable soft tissue seal is important from the prophylaxis point of view. Host and bacterial cell attachment is directly affected by specific material surface characteristics, such as topography and roughness, wettability, electrical charge, and chemical composition. ${ }^{7,8}$ Thus, to improve soft tissue reactivity, surface modification of the implant material should provide a biological interface that facilitates host cell integration while minimizing bacterial adhesion.

The use of zirconia as implant abutment material is rapidly increasing, since it is regarded as being more aesthetic and biologically friendly compared with traditional abutment material, titanium. ${ }^{9}$ However, because it is bioinert and has low reactivity, the use of zirconia is challenging when it comes to fast integration with the surrounding tissue. ${ }^{\mathbf{1 0}}$ To address this issue, several surface modification approaches have been proposed to improve the biological performance of zirconia in terms of tissue responses: (i) modifying the surface topography by grinding, sand blasting, ${ }^{11}$ or etching; ${ }^{\mathbf{1 2}}$ (ii) application of ultraviolet irradiation, ${ }^{13}$ plasma spraying, ${ }^{14}$ or laser treatment; ${ }^{15}$ and (iii) coating of the surface with bioactive agents such as hydroxyapatite, ${ }^{16}$ calcium phosphate, ${ }^{17}$ chitosan, ${ }^{18}$ type I collagen, ${ }^{19}$ and bone morphogenetic protein $2 .^{20}$ Among these techniques, the physical methods require specialized equipment and conditions, while bioactive coatings generally require complicated procedures and frequently demonstrate poor adhesion to the material. Moreover, the major purpose of these surface modification strategies is to promote bone regeneration, while data on their effect on soft tissue healing are lacking. Therefore, there is an urgent need for a simple and effective surface treatment method to improve the bioactivity of zirconia with regard to soft tissue integration.

Functionalization of dental implant surfaces using biomimetic agents is a hot topic in the biological materials research field. ${ }^{\mathbf{1 0 , 2 1}}$ The presence of biomolecules on the surface of biomaterials mimics the native cellular microenvironment in dictate of cell behavior. For example, Arg-Gly-Asp (RGD), a cellbinding sequence derived from the extracellular matrix (ECM) protein such as fibronectin, has been extensively employed because it promotes cell adhesion by activating integrin receptors. RGD-containing peptides enhance the attachment of numerous cell types on various types of biomaterials. ${ }^{22}$ The anchoring of RGD to the substrate determines tissue integration. RGD peptides that detach from the substrate may inhibit cell adhesion by competing with attached RGD for integrin on target cells. ${ }^{21}$ Therefore, efficient immobilization of the RGD peptide is a major concern in the preparation of cell adhesionpromoting surfaces. Various immobilization methods have been developed to tether RGD peptides onto dental implant surfaces, including electrodeposition, ${ }^{23}$ plasma polymerization, ${ }^{24}$ self-assembled monolayers, ${ }^{25}$ and covalent coupling. ${ }^{26}$ However, many of these strategies have limitations, such as low binding stability, low grafting rate, complex chemical processes, use of organic solvents, and being time-consuming and/or costly. ${ }^{27}$ In addition, RGD peptides have been extensively used to coat titanium implants, ${ }^{28-30}$ but rarely for zirconia abutments. Moreover, little is known about the antimicrobial properties of RGD coating. Thus, a facile, efficient, and low-cost immobilization method to stably graft RGD peptides onto zirconia surfaces would be highly beneficial.

Inspired by the bio-adhesion principle of mussels, Messersmith et al. developed a versatile polydopamine (PDA) coating by simply dipping the substrate into an alkaline dopamine solution. The PDA film formed strong adhesive interactions with diverse materials, regardless of their chemistry or geometry. $^{31}$ More importantly, PDA coating facilitates covalent conjugation with biomolecules containing amine and thiol groups via Michael addition or Schiff base reactions, which enables the preparation of various hybrid materials with specific functionalities. Various proteins, peptides, and bioactive molecules have been conjugated onto substrates via the PDA coating layer for different purposes. ${ }^{32,33}$ Previous data from our group demonstrated that PDA is able to modify zirconia surfaces and improve the adherence of HGFs to a certain extent. Moreover, PDA coating also possesses favorable antibacterial properties. ${ }^{34}$ However, PDA coating alone did not sufficiently promote biological behaviors of HGFs. To further improve the specificity of zirconia abutment materials and cell-surface interactions, in the current study, cell adhesion peptides containing RGD sequences were immobilized onto zirconia surfaces via the PDA coating layer. Compared to traditional immobilization approaches, PDA-assisted surface modification exhibits several advantages as (1) it significantly improves the anchoring of biomolecules; (2) it is a simple method that does not require time-consuming synthesis of complex linkers; (3) the process is non-toxic and uses water as a solvent, reducing the risk of damaging the biological activity of the adhesion molecules; and (4) it can be applied to complex geometries. ${ }^{35}$ Chien et al. ${ }^{36,37}$ reported that implant surface functionalization with RGD-conjugated polymers via PDA-assisted immobilization promoted titanium biocompatibility and osteogenic response. However, to the best of our knowledge, the effect of PDA-assisted RGD peptide grafting on soft tissue healing around zirconia abutment surfaces has not yet been explored.

We aimed to develop a facile and effective coating method based on PDA deposition for immobilizing cell-adhesion RGD peptides on zirconia abutment materials to improve soft tissue integration. The effect of peptide-based biomimetic functionalization on bioactivity was assessed using two different types of ligand, i.e., a linear (KGGRGDSP) and a cyclic (c(RGDfK)) RGD peptide. To evaluate the coating efficacy, the biological behavior 
of HGF such as adhesion, spreading, proliferation, and differentiation as well as gene and protein expression were investigated in vitro. Moreover, the effect of immobilized RGD peptide on bacterial adhesion was also studied (Scheme 1).

\section{Materials and methods}

\subsection{Materials}

Zirconia disks (Zenostar, Wieland Dental, Pforzheim, Germany) were cut to $15 \mathrm{~mm}$ in diameter and $2 \mathrm{~mm}$ thick using a cutting machine. The disks were wet-grinded and serially polished with 600-, 800-, and 1200-grit SIC abrasive papers. The crystallographic structure of zirconia was analyzed as reported previously, ${ }^{34}$ and the results showed that it fitted the properties of zirconium yttrium oxide. All disks were washed in an ultrasonic cleaner in absolute ethanol and distilled water for $20 \mathrm{~min}$ each, and then dried in an oven at $50{ }^{\circ} \mathrm{C}$ before surface treatment.

\subsection{Preparation of substrates}

PDA coating was performed as described previously. ${ }^{31}$ Briefly, disks were immersed in dopamine solution $\left(2 \mathrm{mg} \mathrm{mL}^{-1}\right.$ in $10 \mathrm{mM}$ Tris-HCl, pH 8.5, Sigma-Aldrich, St. Louis, MO, USA) and gently shaken at room temperature for $18 \mathrm{~h}$. The PDAcoated disks were extensively rinsed with copious ultrapure water to remove unattached dopamine molecules and then dried under a $\mathrm{N}_{2}$ stream. The disks were then immersed in a solution of adhesion peptides (fibronectin sequences: KGGRGDSP and c(RGDfK); $1 \mathrm{mg} \mathrm{mL}^{-1}$ in $10 \mathrm{mM}$ Tris buffer, $\mathrm{pH}$ 8.5, Chinese Peptide Company, China, ESI Fig. $1 \dagger$ ) at room temperature for $24 \mathrm{~h}$. Then, the disks were sterilized with $75 \%$ ethanol for $40 \mathrm{~min}$ and washed thrice with phosphate-buffered saline (PBS) before use. The substrates were designated $\mathrm{ZrO}_{2}$ (pristine zirconia), $\mathrm{ZrO}_{2}-\mathrm{P}$ (PDA-modified zirconia), and $\mathrm{ZrO}_{2}-\mathrm{P} /$ L (linear peptides, KGGRGDSP-functionalized zirconia) and $\mathrm{ZrO}_{2}-\mathrm{P} / \mathrm{C}$ (cycle peptides, c(RGDfK)-functionalized zirconia). To confirm peptide conjugation, PDA-coated disks were immersed in fluorescein isothiocyanate (FITC)-labeled KGGRGDSP or $\mathrm{c}$ (RGDfK) solution at room temperature for $24 \mathrm{~h}$ and then in $75 \%$ ethanol solution for $40 \mathrm{~min}$, followed by three washes with PBS. Fluorescence images were acquired using a confocal laser scanning microscope (CLSM; LSM710, Zeiss, Oberkochen, Germany) before and after sterilization/rinsing of the modified substrates.

\subsection{Surface characterization}

2.3.1. Surface topography and roughness. Surface topography was observed by atomic force microscopy (AFM; Dimension Icon, Bruker, Billerica, MA, USA) and scanning electron microscopy (SEM; S-4800, Hitachi, Tokyo, Japan). Peak-to-valley surface roughness $\left(R_{\mathrm{a}}\right)$ was determined by AFM. Three samples per group were observed in five random fields per sample.

2.3.2. Surface wettability. Surface wettability was evaluated by measuring the contact angle of a $1 \mu \mathrm{L}$ droplet of doubledistilled water using a contact angle meter (SL200, Kino Industry Co., Ltd, Boston, MA, USA). Measurements were taken at three different locations on each one of three samples per group.

2.3.3. Chemical composition. The chemical composition of the surfaces was analyzed by X-ray photoelectron spectroscopy (XPS; ESCALAB 250, Thermo Fisher Scientific, Waltham, MA, USA). Binding energies were referenced to the $\mathrm{C} 1 \mathrm{~s}$ hydrocarbon peak at $284.6 \mathrm{eV}$.

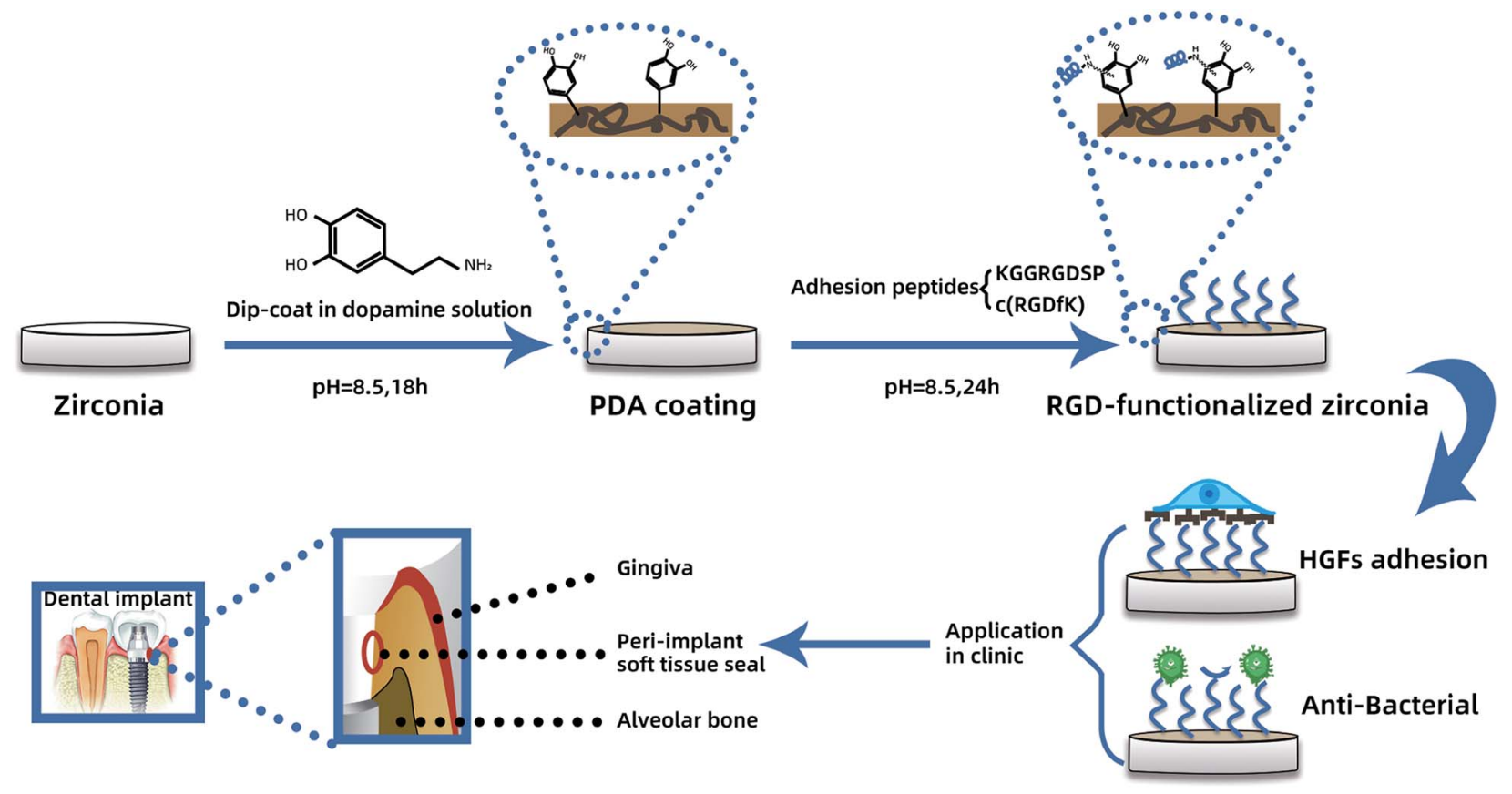

Scheme 1 PDA-mediated RGD functionalization process and its effect on HGFs and bacterial adhesion for enhanced peri-implant soft tissue seal. 


\subsection{Cellular responses}

2.4.1. Cell culture. HGFs were derived from biopsies obtained from a periodontally healthy human subject during periodontal surgery, as previously described. ${ }^{34}$ Cell collection was approved by the Ethics Committee of Peking University School and Hospital of Stomatology, and written informed consent was obtained from the patient. The HGFs were cultured in Dulbecco's modified Eagle's medium (Thermo Fisher Scientific, Gaithersburg, MD, USA) supplemented with $10 \%$ fetal bovine serum (Thermo Fisher Scientific, Gaithersburg, MD, USA) and 1\% antibiotic-antimycotic solution (Thermo Fisher Scientific, Gaithersburg, MD, USA) at $37{ }^{\circ} \mathrm{C}$ under a humidified atmosphere of $5 \% \mathrm{CO}_{2}$ and $95 \%$ air. The culture medium was changed every other day. Confluent cells were subcultured by trypsinization. Cells from passages 3 to 7 were used in the experiments.

2.4.2. Cell adhesion and spreading. HGFs were seeded onto the surfaces of disks in a 24 -well plate at a density of $1.0 \times 10^{5} /$ well. After culturing for $3 \mathrm{~h}$ and $24 \mathrm{~h}$, unattached cells were removed by rinsing with $1 \mathrm{~mL}$ PBS thrice. The attached cells were fixed with $4 \%$ paraformaldehyde at room temperature for $10 \mathrm{~min}$. Subsequently, the cells were permeabilized in $0.1 \%$ Triton X-100 for $7 \mathrm{~min}$, and then blocked with 1\% bovine serum albumin (Sigma, St. Louis, MO, USA) for 15 min to prevent nonspecific binding. After extensive rinsing with PBS $(3 \times 5 \mathrm{~min}$ each), the disks were stained with FITC-phalloidin (actin filaments, green color; 1 : 300, Sigma, St. Louis, MO, USA) for $1 \mathrm{~h}$. Finally, nuclei were counterstained with a drop of Fluoroshield containing 4',6-diamidino-2-phenylindole (blue color; Sigma, St. Louis, MO, USA). Coverslips were mounted on the surfaces, and the cells were observed by CLSM. Attached cells, projected area, and perimeter of HGFs were quantified using ImageJ (version 2, NIH, USA).

2.4.3. Cell proliferation. A Cell Counting Kit-8 (CCK-8; Dojindo, Kyushu, Japan) was used to quantify HGF proliferation. Cells were seeded on modified/unmodified zirconia disks at a density of $1.0 \times 10^{4} /$ well. After incubation for 1,3 , or 5 days, the samples were washed thrice with PBS. CCK-8 solution diluted with cell culture medium $(1: 9, \mathrm{v} / \mathrm{v})$ was added to each well, and the plate was incubated at $37{ }^{\circ} \mathrm{C}$ for $2.5 \mathrm{~h}$. The supernatant was then transferred from the 24 -well to a 96-well cell culture plate and the absorption at $450 \mathrm{~nm}$ was measured using a spectrophotometer (ELX808, BioTek, Winooski, VT, USA).

2.4.4. Gene expression analysis. Relative gene expression levels of integrin $\alpha 5$, integrin $\beta 1$, focal adhesion kinase (FAK), vinculin (VCL), fibronectin (FN), and human collagen type I (Col-1) in HGFs seeded on zirconia disks of different groups were determined by quantitative reverse-transcription polymerase chain reaction (RT-qPCR). Total mRNA was extracted from 1 day cultures using TRIzol reagent (Invitrogen, Grand Island, NY, USA), and cDNA was generated using the RevertAid First Strand cDNA Synthesis Kit (Thermo Fisher Scientific, Waltham, MA, USA) according to the manufacturer's instructions. qPCRs were run using Power SYBR Green PCR Master Mix (Thermo Fisher Scientific, Waltham, MA, USA) and specific primers (Table 1) on a 7500 Real-time PCR System (Thermo Fisher Scientific, Waltham, MA, USA). GADPH was used as the reference gene. Relative expression levels were calculated using the $2^{-\Delta \Delta \mathrm{C}_{\mathrm{T}}}$ method and are presented as fold differences relative to the control group.

2.4.5. Protein determination. Col-1 secretion by HGFs after 3 and 7 days of incubation was quantified using an enzymelinked immunosorbent assay kit (ELISA; R\&D Systems, Minneapolis, MN, USA) according to the manufacturer's protocol. In brief, cell culture supernatants were collected and centrifuged at $3000 \times g$ at $4{ }^{\circ} \mathrm{C}$ for $10 \mathrm{~min}$ to remove particles and polymer. In each well of a 96 -well plate, $10 \mu \mathrm{L}$ of sample, $40 \mu \mathrm{L}$ of sample diluent, and $100 \mu \mathrm{L}$ of HRP-conjugate reagent were added, followed by incubation at $37^{\circ} \mathrm{C}$ for $1 \mathrm{~h}$. After rinsing the wells with washing buffer five times, $50 \mu \mathrm{L}$ of chromogen solutions $\mathrm{A}$ and $\mathrm{B}$ were added into each well, and the plate was incubated at $37^{\circ} \mathrm{C}$ in the dark for $15 \mathrm{~min}$. Finally, $50 \mu \mathrm{L}$ of stop solution was added to each well to terminate the reaction. Absorbance at $450 \mathrm{~nm}$ was measured using a microplate reader and was used to estimate the protein concentration of the samples.

\subsection{Bacterial responses}

2.5.1. Saliva coating of zirconia disks. Saliva was collected from seven healthy donors as described previously, ${ }^{34}$ and was centrifuged at $3000 \mathrm{rpm}$ at $4{ }^{\circ} \mathrm{C}$ for $20 \mathrm{~min}$ to remove impurities. The clarified saliva was diluted with distilled water at a volume ratio of $1: 3$, passed through a $0.20 \mu \mathrm{m}$ filter, and stored at $-80{ }^{\circ} \mathrm{C}$ until use. Immediately before use, the frozen saliva was thawed in a water bath at $37^{\circ} \mathrm{C}$ and centrifuged at $1430 \times g$ for 5 min to obtain clear supernatant. Zirconia disks were immersed in the clear supernatant at $37{ }^{\circ} \mathrm{C}$ for $4 \mathrm{~h}$ to form a saliva film for bacterial adhesion.

2.5.2. Bacterial cultures. The antimicrobial activity of modified/unmodified samples was evaluated using Grampositive Streptococcus mutans (strain UA159, provided by the Institute of Microbiology at the Chinese Academy of Sciences) and Gram-negative Porphyromonas gingivalis (strain W83, provided by the Central Laboratory of Peking University School of Stomatology). S. mutans and P. gingivalis were maintained on brain heart infusion agar plates (BHI, BD-Difco, Franklin, NJ, USA). S. mutans was maintained at $37^{\circ} \mathrm{C}$ in a humidified atmosphere of $5 \% \mathrm{CO}_{2}$ and $95 \%$ air. $P$. gingivalis was maintained under standard anaerobic conditions $\left(80 \% \mathrm{~N}_{2}, 10 \% \mathrm{H}_{2}\right.$, $10 \% \mathrm{CO}_{2}$ ), at $37{ }^{\circ} \mathrm{C}$. Monoclonal strains of the two species were separately transferred into $1 \mathrm{~mL}$ of liquid $\mathrm{BHI}$ medium and cultured to the exponential phase for use. Bacterial cells were centrifuged at $3000 \times g$ for $15 \mathrm{~min}$, and the cell pellet was washed twice with $0.15 \mathrm{M}$ PBS buffer. The cells were resuspended at different final concentrations. Before seeding, the suspension was shaken for $30 \mathrm{~s}$ to obtain single cells or pairs. Cells were seeded on sterile samples in a 24-well plate for further experiments.

2.5.3. Bacterial adhesion. Bacteria $\left(1 \times 10^{8} \mathrm{CFU} \mathrm{mL} \mathrm{mL}^{-1}\right)$ were cocultured with saliva-coated zirconia disks for $3 \mathrm{~h}(S$. mutans) or $48 \mathrm{~h}$ (P. gingivalis) for SEM and CLSM observation. After removing the culture medium, the cells were gently 
Table 1 Primer pairs used in real-time PCR analysis

Sequences $\left(5^{\prime}-3^{\prime}\right)$

$\begin{array}{ll}\text { Forward Reverse } & \end{array}$

\section{Gene}

Forward

GGCATCAGAGGTGGCTGGAGG

Integrin $\alpha 5$

Integrin $\beta 1$

Fibronectin

Focal adhesion kinase

Vinculin

Collagen type I

GAPDH

\author{
GGCAGCTATGGCGTCCCACTGTG \\ CAAAGGAACAGCAGAGAAGC \\ CGGAGAGACAGGAGGAAATAGCC \\ CTCCTACTGCCAACCTGGAC \\ CGAATCCCAACCATAAGCAC \\ AGAGCATGACCGATGGATTC \\ TGCACCACCAACTGCTTAGC
}

ATTGAGTAAGACAGGTCCATAA

TTGCTGCTTGCGGGGCTGTC

GCCGACTTCCTTCACCATAG

CGCACAGTCTCCTTCACAGA

TTCTTGAGGTTGCCAGTC

GGCATGGACTGTGGTCATGAG washed with sterile PBS to remove non-attached cells. Adherent bacteria on the disks were fixed with $2.5 \%$ glutaraldehyde at room temperature for $60 \mathrm{~min}$. After three washes with PBS, the disks were dehydrated in a graded series of ethanol $(25 \%, 50 \%$, $70 \%, 90 \%, 95 \%$, and $100 \%$ ) for $10 \mathrm{~min}$. Finally, the disks were dried, sputter-coated with gold, and imaged by SEM.

The LIVE/DEAD BacLight Bacterial Viability Kit (Invitrogen, Carlsbad, CA, USA) was used to examine live (green-fluorescent) and dead (red-fluorescent) bacteria. The staining components A (SYTO 9) and B (propidium iodide) were mixed and diluted in PBS at a volume ratio of $1.5: 1000$ according to the manufacturer's instructions. Three hundred microliters of mixed staining dilution was added to each sample, followed by incubation at $37{ }^{\circ} \mathrm{C}$ in the dark for $15 \mathrm{~min}$. The stained bacteria were observed by CLSM. Digital images were acquired for five random fields on each surface. The percentage of area covered by bacteria in each image was quantified using Image $\mathrm{J}$ software.

\subsection{Statistical analysis}

All experiments were performed three times independently, in triplicate. All data are expressed as the mean \pm standard deviation (SD). Statistical analysis was performed using one-way analysis of variance (ANOVA) followed by Tukey tests. $p<0.05$ was considered statistically significant.

\section{Results and discussion}

\subsection{Functionalization characterization}

The topographies of pristine and decorated zirconia were observed by SEM and AFM (Fig. 1). Self-polymerized PDA particulates were observed on the $\mathrm{ZrO}_{2}$-P surface. Immobilization of KGGRGDSP and c(RGDfK) peptides increased the PDA particulate size, suggesting that RGD peptides were successfully grafted onto the zirconia substrate surface. Surface roughness was determined by AFM (Table 2). After PDA coating, the $R_{\mathrm{a}}$ value increased slightly, albeit not significantly, from $0.207 \pm$ $0.009 \mu \mathrm{m}$ to $0.217 \pm 0.005 \mu \mathrm{m}$. Chemical coupling of RGD peptides on the $\mathrm{ZrO}_{2}-\mathrm{P}$ surface did not affect the $R_{\mathrm{a}}$ values $(0.222$ $\pm 0.008 \mu \mathrm{m}$ for $\mathrm{ZrO}_{2}-\mathrm{P} / \mathrm{L}$ and $0.214 \pm 0.008 \mu \mathrm{m}$ for $\left.\mathrm{ZrO}_{2}-\mathrm{P} / \mathrm{C}\right)$. Surface topography is a key factor affecting the biological responses of host cells and bacteria. ${ }^{38}$ Abutment surfaces with micro-roughness $(3-30 \mu \mathrm{m})$ have been suggested to inhibit epithelial down growth, ${ }^{39}$ whereas bacterial colonization increased with a roughness $>0.2 \mu \mathrm{m} .{ }^{40}$ Taking these factors into account, Gehrke et al. proposed an abutment-surface-roughness classification method for clinical practice, and determined the optimal surface roughness for the trans-mucosal portion of implant abutments that strikes a balance between soft tissue sealing and bacterial adhesion to be $0.15-0.25 \mu \mathrm{m}^{41}$ Therefore, the zirconia disks used in this study were polished to $0.2 \mu \mathrm{m}$ to mimic the transgingival surface of commercially available zirconia abutments. The $R_{\mathrm{a}}$ values did not significantly differ between unmodified and modified zirconia, indicating that changes in cellular response and bacterial colonization on different substrates might have little to do with surface roughness.

Surface wettability of pristine and decorated zirconia substrates was determined by water contact angle measurements (Table 2). After PDA deposition, the contact angle significantly decreased from $72.8 \pm 2.3^{\circ}$ to $61.9 \pm 2.6^{\circ}(p<0.05)$. Immobilization of RGD peptides onto the $\mathrm{ZrO}_{2}-\mathrm{P}$ surface further decreased the contact angle $\left(46.5 \pm 1.4^{\circ}\right.$ on $\mathrm{ZrO}_{2}-\mathrm{P} / \mathrm{L}$ and $45.2 \pm$ $2.2^{\circ}$ on $\left.\mathrm{ZrO}_{2}-\mathrm{P} / \mathrm{C}\right)$, likely because of the hydrophilic groups $\left(-\mathrm{OH},-\mathrm{COOH}\right.$, and $\left.-\mathrm{NH}_{2}\right)$ of the grafted peptides. These gradual changes in the static contact angle indicated successful PDA coating and functionalization with RGD peptides. Surface wettability is another pivotal factor influencing peri-implant soft tissue integration. Kloss et al. reported that hydrophilic surfaces promoted connective tissue attachment and cellsurface contacts, and suppressed inflammatory responses. ${ }^{42}$ In the present study, surface wettability increased after the grafting of RGD peptides. Thus, immobilization of KGGRGDSP and c(RGDfK) on zirconia abutments may promote soft tissue healing.

Stable immobilization of RGD peptides onto the substrate is crucial for promoting strong cell adhesion, as focal adhesion formation occurs only when the ligands can withstand cell contractile forces. ${ }^{43}$ These forces can redistribute weakly adsorbed ligands on the substrate, leading to weak fibrillar adhesions. ${ }^{44}$ Thus, for stable linkage, the RGD peptides should ideally be covalently attached to the substrate. We investigated RGD peptide immobilization by using FITC-labeled KGGRGDSP and $\mathrm{c}(\mathrm{RGDfK})$ peptides that were chemically coupled to $\mathrm{ZrO}_{2}-\mathrm{P}$ surfaces. Fig. 2 shows fluorescence images of CLSM of the substrate surfaces. Before RGD coating, there was almost no 


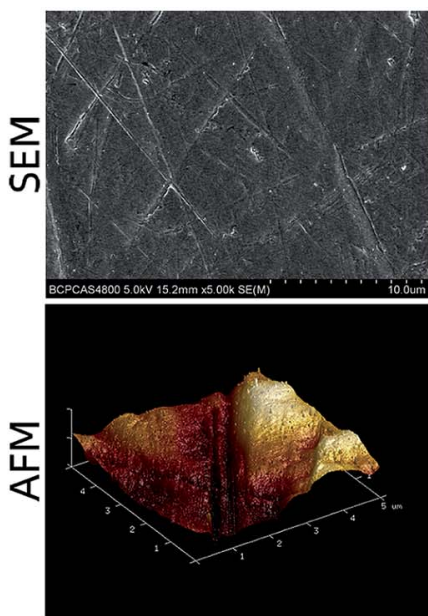

$\mathrm{ZrO}_{2}$
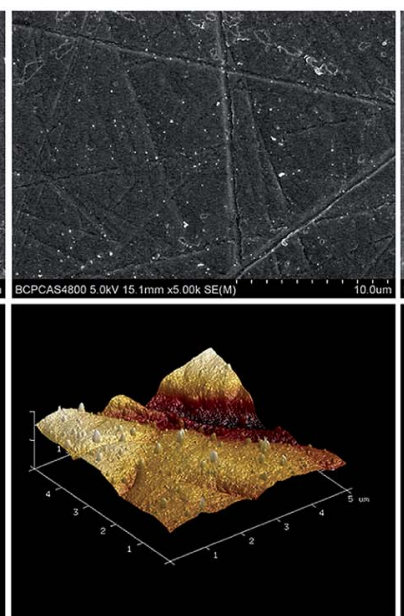

$\mathrm{ZrO}_{2}-\mathrm{P}$

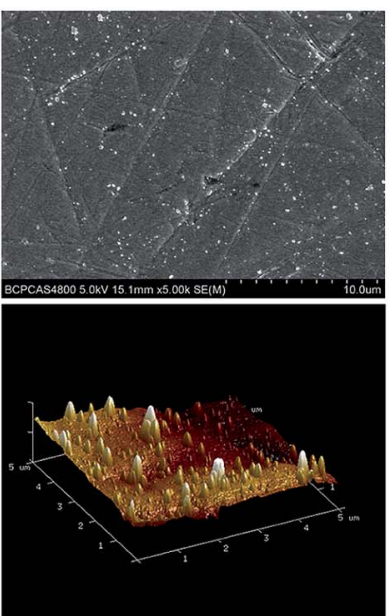

$\mathrm{ZrO}_{2}-\mathrm{P} / \mathrm{L}$
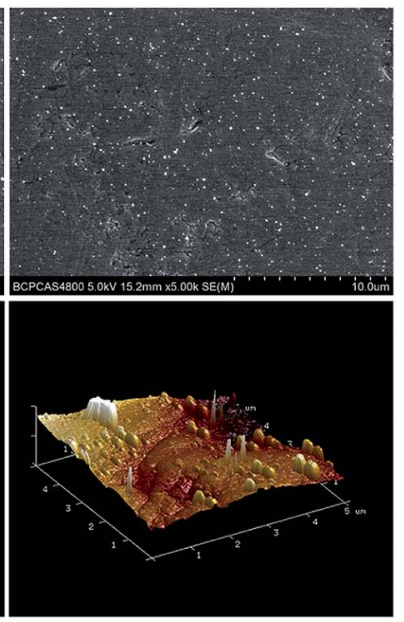

$\mathrm{ZrO}_{2}-\mathrm{P} / \mathrm{C}$

Fig. 1 Surface topography of zirconia substrates: AFM and SEM images of the pristine zirconia, PDA-coated zirconia, and RGD-functionalized zirconia.

noticeable fluorescent signal on $\mathrm{ZrO}_{2}$ and $\mathrm{ZrO}_{2}-\mathrm{P}$ surfaces. In contrast, after grafting RGD on PDA film, punctate green fluorescence was observed on the $\mathrm{ZrO}_{2}-\mathrm{P} / \mathrm{L}$ and $\mathrm{ZrO}_{2}-\mathrm{P} / \mathrm{C}$ surfaces. After immersing the disks of $\mathrm{ZrO}_{2}-\mathrm{P} / \mathrm{L}$ and $\mathrm{ZrO}_{2}-\mathrm{P} / \mathrm{C}$ in $75 \%$ alcohol solution for $40 \mathrm{~min}$ and washing them thrice with PBS, the fluorescence was slightly reduced, but still visible. RGD peptides physically adsorbed on the surface were washed away after alcohol immersion and multiple washing steps; the remaining peptides were covalently coupled onto the PDA coating.

The atomic chemical composition of the functionalized zirconia surfaces was analyzed by XPS. The wide scan spectra of the various surfaces are shown in Fig. $3 \mathrm{~A} . \mathrm{ZrO}_{2}$ substrate displayed strong $\mathrm{Zr} 3 \mathrm{~d}, \mathrm{O} 1 \mathrm{~s}$, and $\mathrm{C} 1 \mathrm{~s}$ peaks. The presence of PDA on the zirconia surface could be deduced from the appearance of the $\mathrm{N} 1 \mathrm{~s}$ peak and the decrease of the $\mathrm{Zr} 3 \mathrm{~d}$ peak. ${ }^{34}$ Following RGD immobilization, the $\mathrm{N}$ 1s peak strongly increased, indicating successful anchoring of the cell adhesion peptides. These results were confirmed by elemental percentage changes summarized in Fig. 3B. The nitrogen content was strongly increased after RGD modification (from $3.42 \%$ on $\mathrm{ZrO}_{2}$ and $6.56 \%$ on $\mathrm{ZrO}_{2}-\mathrm{P}$ to $13.02 \%$ on $\mathrm{ZrO}_{2}-\mathrm{P} / \mathrm{L}$ and $13.85 \%$ on $\mathrm{ZrO}_{2}-\mathrm{P} /$ C) because of the amine groups and peptide bonds in the peptides. To obtain the detailed chemical composition of each sample, C 1s peak fitting was further analyzed (Fig. 3C). The

Table 2 Quantitative measurement of water contact angle and surface roughness

\begin{tabular}{lll}
\hline & Roughness $(\mu \mathrm{m})$ & $\begin{array}{l}\text { Water contact } \\
\left.\text { angle }{ }^{\circ}\right)\end{array}$ \\
\hline $\mathrm{ZrO}_{2}$ & $0.207 \pm 0.009$ & $72.8 \pm 2.3$ \\
$\mathrm{ZrO}_{2}-\mathrm{P}$ & $0.217 \pm 0.005$ & $61.9 \pm 2.6$ \\
$\mathrm{ZrO}_{2}-\mathrm{P} / \mathrm{L}$ & $0.222 \pm 0.008$ & $46.5 \pm 1.4$ \\
$\mathrm{ZrO}_{2}-\mathrm{P} / \mathrm{C}$ & $0.214 \pm 0.008$ & $45.2 \pm 2.2$
\end{tabular}

high-resolution $\mathrm{C}$ 1s spectrum of $\mathrm{ZrO}_{2}$ was deconvoluted into three curves with binding energy at $284.8 \mathrm{eV}(\mathrm{C}-\mathrm{C} / \mathrm{C}-\mathrm{H})$, $286.5 \mathrm{eV}(\mathrm{C}-\mathrm{O})$, and $288.8 \mathrm{eV}(\mathrm{C}=\mathrm{O})$. After PDA coating, the $\mathrm{C}-\mathrm{O}$ and $\mathrm{C}=\mathrm{O}$ peaks were increased, whereas the $\mathrm{C}-\mathrm{C} / \mathrm{C}-\mathrm{H}$ peak was
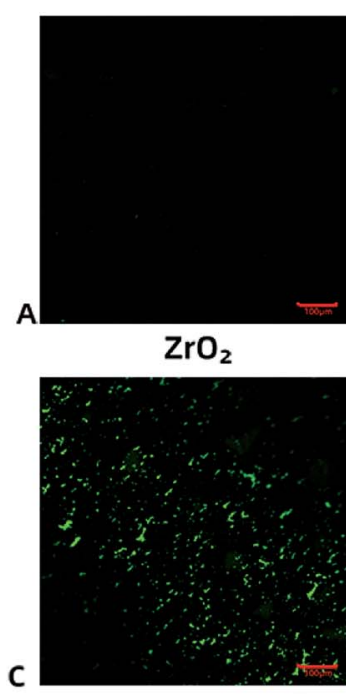

$\mathrm{ZrO}_{2}-\mathrm{P} / \mathrm{L}$

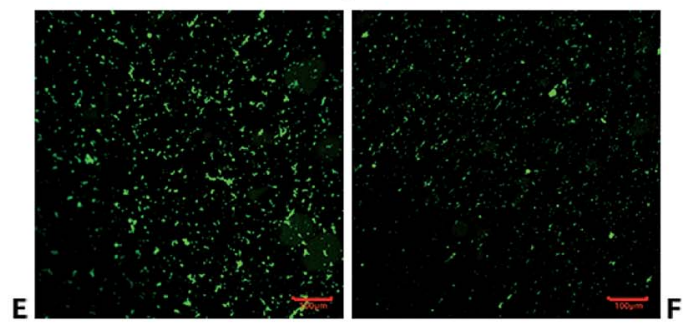

$\mathrm{ZrO}_{2}-\mathrm{P} / \mathrm{C}$

Fig. 2 No noticeable fluorescent signal was observed on $\mathrm{ZrO}_{2}(\mathrm{~A})$ and $\mathrm{ZrO}_{2}-\mathrm{P}(\mathrm{B})$ surfaces. Punctate green fluorescence was observed on the $\mathrm{ZrO}_{2}-\mathrm{P} / \mathrm{L}(\mathrm{C})$ and $\mathrm{ZrO}_{2}-\mathrm{P} / \mathrm{C}$ (E) surfaces. Reduced green fluorescence were observed on $\mathrm{ZrO}_{2}-\mathrm{P} / \mathrm{L}(\mathrm{D})$ and $\mathrm{ZrO}_{2}-\mathrm{P} / \mathrm{C}$ (F) surfaces after rinsing. 

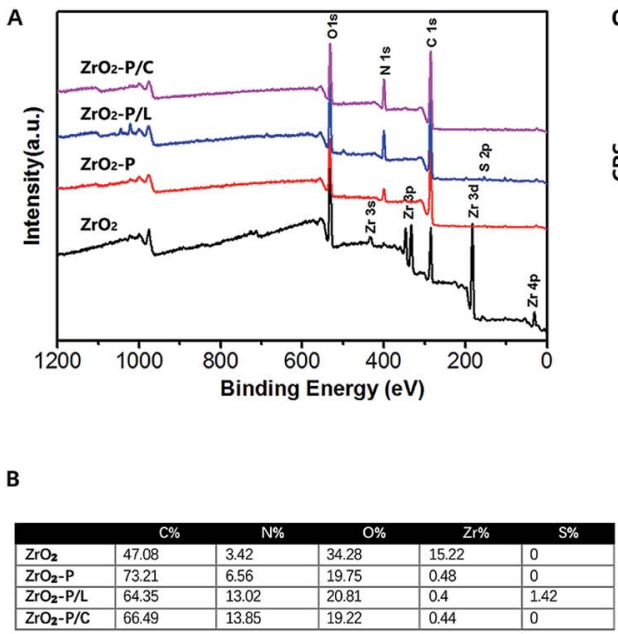

C
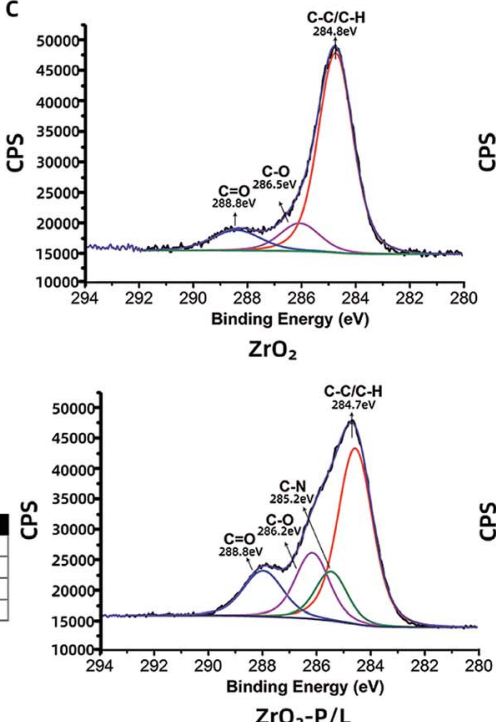
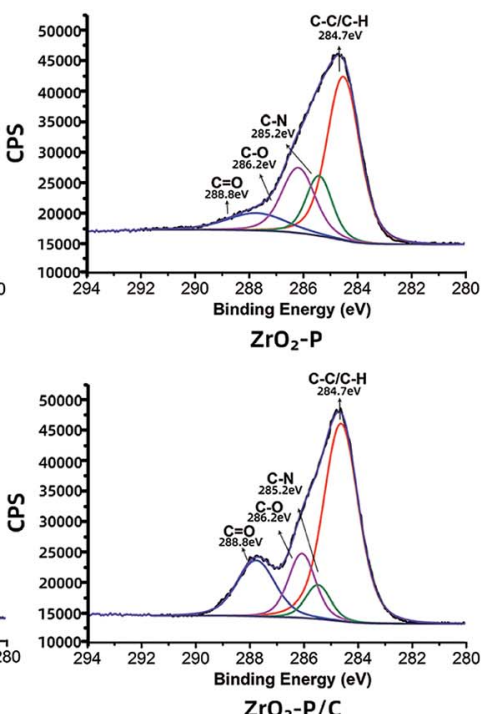

Fig. 3 (A) XPS wide-scan spectra of different groups; (B) quantification in (\%) of atomic compositions on the unmodified and modified zirconia surfaces; (C) typical high-resolution XPS C 1s spectra for different substrates. The ordinate CPS (counts per second) represents the relative photoelectron intensity.

dramatically decreased, which is attribute to the catechol/ quinone groups of PDA. Compared with that of $\mathrm{ZrO}_{2}-\mathrm{P}$, the $\mathrm{C}=\mathrm{O}$ peak was significantly increased after RGD peptide grafting due to abundant amide bonds $(-\mathrm{NH}-\mathrm{C}=\mathrm{O})$. Together, these results suggested that RGD peptides can be covalently immobilized onto zirconia surfaces via PDA coating.

\subsection{HGF responses}

3.2.1. HGF adhesion, spreading, and proliferation. As one of the major cells of peri-implant soft tissue, HGFs synthesize and maintain the ECM, which plays a primary role in tissue repair and regeneration during wound healing. ${ }^{45}$ Therefore, enhancing the biological response of HGFs by modifying the zirconia abutment surface might improve peri-implant soft tissue closure. When implant is placed into a host and comes into contact with HGFs, the initial step is cell attachment, which is crucial for subsequent cellular behaviors, such as spreading, proliferation, and differentiation. ${ }^{44}$ We employed CLSM to observe the adhesion and morphology of HGFs on pristine and modified zirconia surfaces (Fig. 4). At $3 \mathrm{~h}$ after cell seeding, HGFs on $\mathrm{ZrO}_{2}$ were round-shaped, with few cellular processes-
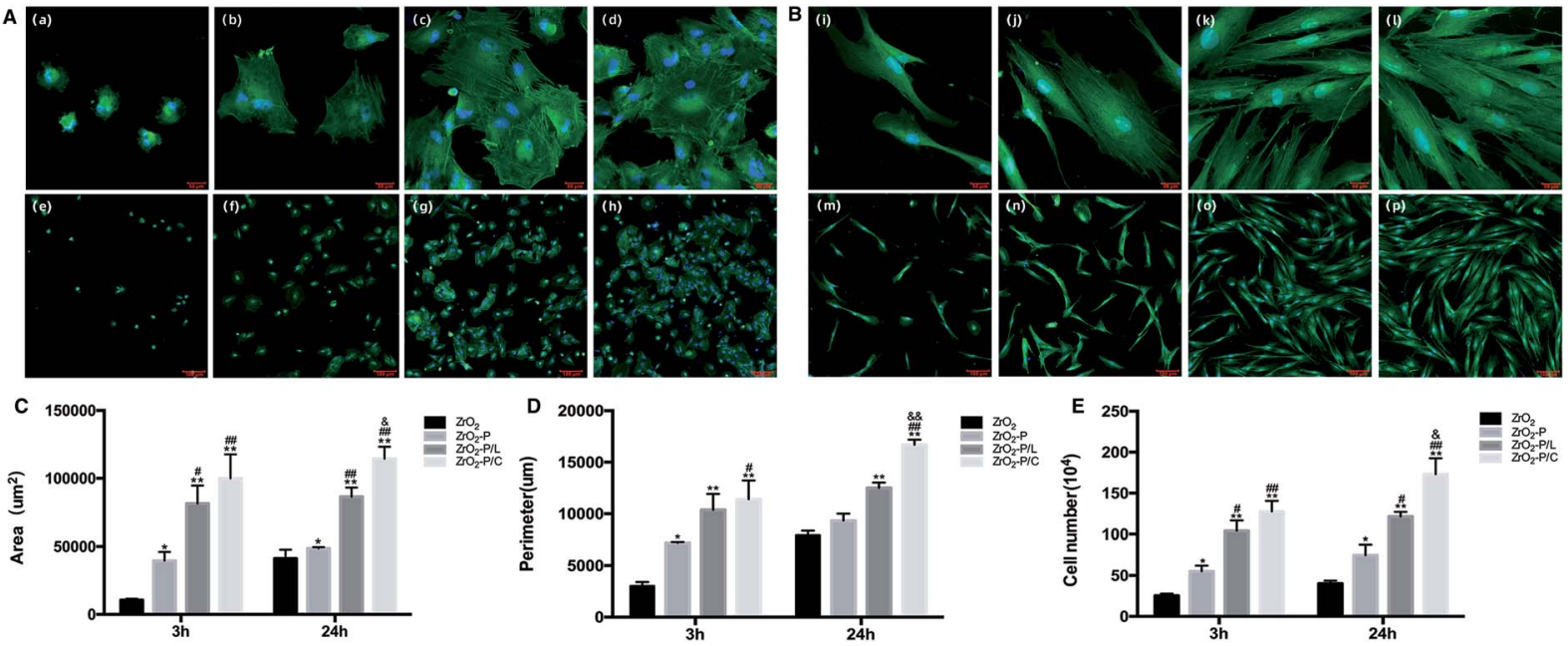

Fig. 4 Confocal laser scanning microscopy images of HGFs on pristine zirconia (a, e, i, m), $\mathrm{ZrO}_{2}-\mathrm{P}(\mathrm{b}, \mathrm{f}, \mathrm{j}, \mathrm{n}), \mathrm{ZrO} \mathrm{Zr}_{2}-\mathrm{P} / \mathrm{L}(\mathrm{c}, \mathrm{g}, \mathrm{k}, \mathrm{o}), \mathrm{and} \mathrm{ZrO} \mathrm{O}_{2}-\mathrm{P} / \mathrm{C}$ $(d, h, l, p)$ surfaces after $3 \mathrm{~h} \mathrm{(A)}$ and $24 \mathrm{~h}$ (B) of culture. High magnification (a, b, c, d, i, j, k, l): scale bar = $20 \mu \mathrm{m}$; low magnification (e, f, g, h, m, h, o, p): scale bar $=100 \mu \mathrm{m}$. Quantitative results for spreading areas (C), perimeters (D), and numbers (E) of HGFs cultured for $3 \mathrm{~h}$ and $24 \mathrm{~h}$ on different substrates. Data are shown as mean \pm SD $(n=15)$. * represents $p<0.05$ and ** represents $p<0.01$, compared with pristine zirconia. ${ }^{*}$ represents $p<0.05$ and ${ }^{\# \#}$ represents $p<0.01$, compared with $\mathrm{ZrO}_{2}-\mathrm{P}$. ${ }^{8}$ represents $p<0.05$ and ${ }^{\& \&}$ represents $p<0.01$, compared with $\mathrm{ZrO} 2-\mathrm{P} / \mathrm{L}$. 
a typical non-spreading morphology. Cells cultured on $\mathrm{ZrO}_{2}-\mathrm{P}$ surfaces for $3 \mathrm{~h}$ had spread over a larger area. On $\mathrm{ZrO}_{2}-\mathrm{P} / \mathrm{L}$ and $\mathrm{ZrO}_{2}-\mathrm{P} / \mathrm{C}$ surfaces, the cells had spread more extensively, and filopodium-like processes appeared. Subsequently, cell membrane protrusions formed further, resulting in rapid cell spreading and formation of bridge connections between adjacent cells on the modified zirconia surfaces after $24 \mathrm{~h}$ of incubation, particularly in the $\mathrm{ZrO}_{2}-\mathrm{P} / \mathrm{L}$ and $\mathrm{ZrO}_{2}-\mathrm{P} / \mathrm{C}$ groups. In comparison, cells cultured on $\mathrm{ZrO}_{2}$ surfaces had a spindle-like and narrow shape, with fewer protrusions, and there were fewer cells. The differences observed in cell attachment and morphology were quantified by counting adhered cells and measuring their area and perimeter (Fig. 4C-E). HGF number, projected area, and perimeter were all increased after PDA coating, which was consistent with findings in our previous study. ${ }^{34}$ RGD functionalization further increased the adhesion and spreading of adherent cells at both $3 \mathrm{~h}$ and $24 \mathrm{~h}$. Cell number, projected area, and perimeter were the highest on $\mathrm{ZrO}_{2}-\mathrm{P} / \mathrm{C}$, indicating a high degree of adhesion and spreading. These results indicated that PDA-mediated functionalization of zirconia substrates with RGD peptides, especially cyclic peptides, promotes HGF attachment and spreading.

The proliferation of HGFs cultured on the different substrates was detected by CCK- 8 assay on days 1,3 , and 5 (Fig. 5). The proliferation of adhered HGFs increased with increasing culture time in all groups. There were no statistically significant differences among the four groups on day 1 . On days 3 and 5, proliferation was the highest on RGD-decorated surfaces, followed by $\mathrm{ZrO}_{2}-\mathrm{P}$, and then $\mathrm{ZrO}_{2}$. HGF proliferation was higher on $\mathrm{ZrO}_{2}-\mathrm{P} / \mathrm{C}$ than on $\mathrm{ZrO}_{2}-\mathrm{P} / \mathrm{L}$, especially after 5 days $(p<0.05)$. These results indicated that RGD peptides effectively stimulate HGF proliferation, with cyclic performing slightly better than linear peptides.

3.2.2. Gene expression and protein synthesis in HGFs. Integrin-mediated cell adhesion comprises several cascade events: cell attachment, cell spreading, organization of the actin cytoskeleton, and formation of focal adhesions. ${ }^{46}$ Integrins are a family of transmembrane glycoprotein receptors that regulate cell adhesion by attaching intracellular cytoskeletal elements to

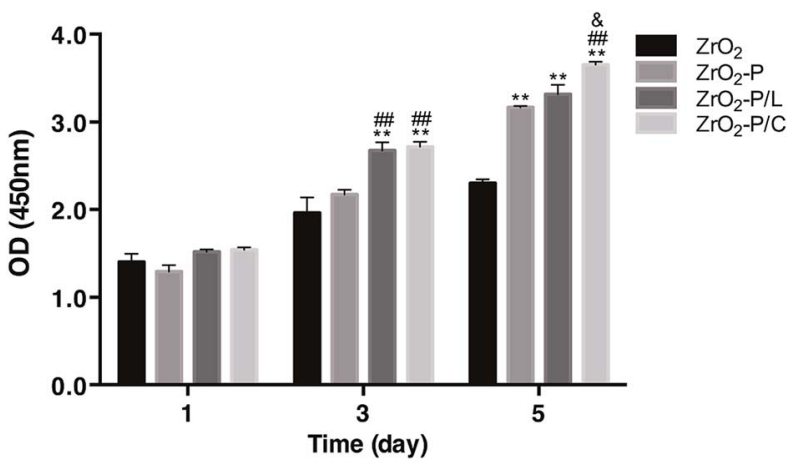

Fig. 5 The proliferation of HGFs cultured on different substrates for 1 , 3 , and 5 days was evaluated by CCK- 8 assay. * represents $p<0.05$ and ** represents $p<0.01$, compared with pristine zirconia. ${ }^{\# \#}$ represents $p$ $<0.01$, compared with $\mathrm{ZrO}_{2}-\mathrm{P}$. ${ }^{\&}$ represents $p<0.05$, compared with $\mathrm{ZrO}_{2}-\mathrm{P} / \mathrm{L}$. extracellular molecules. RGD sequence, as the central cell binding domain of FN, can bind cell membrane integrins and thus mediate cell adhesion. ${ }^{47}$ Integrin $\alpha 5 \beta 1$ is a key receptor of RGD and plays a predominant role in fibroblast adhesion. ${ }^{48}$ Thus, RGD peptide modification of zirconia surfaces might enhance the affinity of HGFs towards the substrate via $\alpha 5 \beta 1-$ RGD interactions. Moreover, the binding of $\alpha 5 \beta 1$ and FN mediates FN fibril formation and controls ECM assembly, which is critical for cellular function in vivo. ${ }^{49}$ Indeed, FN, which is abundantly expressed by fibroblasts, can modulate several physiological and pathological processes, including tissue repair and wound healing. ${ }^{50}$ According to RT-qPCR results (Fig. 6), gene expression of integrin $\alpha 5$ in HGFs was increased on $\mathrm{ZrO}_{2}-\mathrm{P}$ compared to $\mathrm{ZrO}_{2}(p<0.05)$, consistent with previous findings, ${ }^{34}$ and even more so on $\mathrm{ZrO}_{2}-\mathrm{P} / \mathrm{L}$ and $\mathrm{ZrO}_{2}-\mathrm{P} / \mathrm{C}(p<$ 0.01 ), while there was no significant difference between the two RGD peptides $(p>0.05)$. Integrin $\beta 1$ gene expression was increased after PDA and RGD modifications, and significantly so on $\mathrm{ZrO}_{2}-\mathrm{P} / \mathrm{C}(p<0.05)$. FN gene expression was significantly higher on $\mathrm{ZrO}_{2}-\mathrm{P}$ and $\mathrm{ZrO}_{2}-\mathrm{P} / \mathrm{C}$ than on $\mathrm{ZrO}_{2}(p<0.01)$. These results implied that PDA-mediated RGD immobilization might promote early adhesion of HGFs by stimulating integrin expression and ECM secretion. The binding of integrins to RGDcontaining ECM proteins leads to the assembly of focal adhesions (FAs), which play a crucial role in cellular adhesion and sensing of the external environment. FAs are closed junctions between the cell and a substrate, where integrins link the ECM to the actin cytoskeleton. Among the three main ways of contact between fibroblasts and substrate materials, i.e., FAs, close contacts, and ECM contacts, FAs are considered to be the tightest. ${ }^{51}$ FAs not only transmit force at adhesion sites to maintain strong attachments to the ECM, but also act as signaling centers from which numerous intracellular pathways emanate to regulate cell behaviors. ${ }^{52}$ During FA assembly, integrins cluster into supramolecular complexes with signaling molecules such as focal adhesion kinase (FAK), as well as structural proteins such as vinculin. FAK is a vital non-receptor tyrosine kinase that regulates cell adhesion signaling and mechanosensing. ${ }^{53}$ Vinculin is a key regulator of adhesion

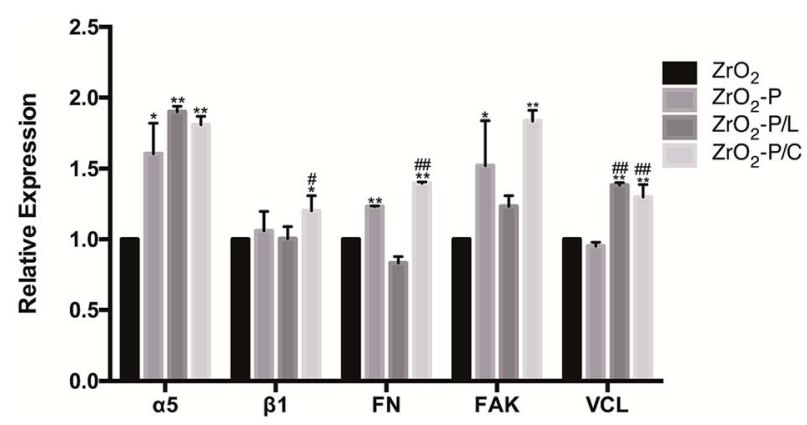

Fig. 6 Analyses on the expressions of genes involved in HGFs adhesion after $24 \mathrm{~h}$ of culture in real-time PCR. Data represent fold changes of target genes relative to the GAPDH expression and the HGFs grew on pristine zirconia (100\%). * represents $p<0.05$ and ** represents $p<$ 0.01 , compared with pristine zirconia. \# represents $p<0.05$ and \#\# represents $p<0.01$, compared with $\mathrm{ZrO}_{2}-\mathrm{P}$. 
strength and cell migration. ${ }^{54}$ FAK gene expression in HGFs was increased in all three experimental groups when compared with the control group, particularly on $\mathrm{ZrO}_{2}-\mathrm{P} / \mathrm{C}(p<0.01)$ and $\mathrm{ZrO}_{2}-\mathrm{P}$ $(p<0.05)$. Vinculin gene expression was significantly higher on $\mathrm{ZrO}_{2}-\mathrm{P} / \mathrm{C}$ and $\mathrm{ZrO}_{2}-\mathrm{P}-\mathrm{L}$ than on $\mathrm{ZrO}_{2}(p<0.01)$, indicating that FA assembly might be promoted. These findings implied that the immobilized RGD peptides enhanced the interaction between HGFs and zirconia surfaces, which might provide a foundation for strong adhesion of HGFs and subsequently tight sealing of soft tissue around zirconia abutments in clinic.

HGFs participate in the formation of connective tissue around an implant during wound healing by producing ECM factors such as collagen type I (Col-1). ${ }^{55}$ We quantified Col-1 expression at both the gene and protein levels to investigate the functional development of HGFs on the different modified surfaces (Fig. 7). After 3 days of incubation, Col-1 gene expression was similar among all substrates, whereas protein expression was slightly higher on $\mathrm{ZrO}_{2}-\mathrm{P} / \mathrm{L}$ and especially, $\mathrm{ZrO}_{2}$ $\mathrm{P} / \mathrm{C}$, than in the control group $(p<0.05)$. The difference between the two RGD peptides was not significant $(p>0.05)$. After 7 days of culture, higher Col-1 gene and protein expression were observed in all functionalized groups, and particularly, significant differences were observed for $\mathrm{ZrO}_{2}-\mathrm{P} / \mathrm{L}(p<0.01$ at the gene level and $p<0.05$ at the protein level). In addition, HGFs cultured on $\mathrm{ZrO}_{2}-\mathrm{P} / \mathrm{L}$ displayed higher Col-1 gene expression than those cultured on $\mathrm{ZrO}_{2}-\mathrm{P} / \mathrm{C}$ for 7 days. These results suggested that KGGRGDSP and c(RGDfK) promote Col-1 secretion. Moreover, cyclic and liner RGD peptides promote cell differentiation in a similar manner, with only subtle evidence of superiority of the linear RGD modification.

RGD-containing peptides are commonly utilized to direct cell adhesion behaviors on biomaterials. ${ }^{56}$ Depending on the spatial structure, they are divided into linear and cyclic peptides. Cyclic peptides mimic the active conformation of the bound form and have a 20-100 fold stronger affinity for integrins than linear RGD peptides, especially for $\alpha \mathrm{V} \beta 3$, $\alpha \mathrm{II} \beta 3$, and $\alpha \nu \beta 5 .{ }^{44}$ Moreover, the ring structure increases the rigidity of the peptide and protects it from degradation. ${ }^{57}$ In comparison, linear peptides, such as GRGDSP, have comparable affinity to $\alpha 5 \beta 1, \alpha \mathrm{V} \beta 3$, and $\alpha \mathrm{II} \beta 3$ at an intermediate level. ${ }^{46}$ Different conformations of immobilized RGD promote differential cell type-dependent responses to material surfaces. As for bonerelated cells, cyclic RGD peptides have been extensively employed, and they are more effective in improving osteoblast behavior and stimulating peri-implant bone formation than linear RGD peptides. ${ }^{21}$ However, as for soft tissue healing, conflicting results on the effects of cyclic and linear RGD peptides on fibroblasts have been reported. Kato et al. found that 3T3 Swiss fibroblasts adhered approximately two times faster to cyclic RGDfK than to linear RGDS, and more, but smaller focal contacts were formed when the cyclic peptide was used. $^{58}$ Wohlrab et al. reported that the binding activity of a linear RGD (in a genetically engineered hybrid silk protein) to BALB/3T3 fibroblasts was indistinguishable from that of a cyclic RGD (chemically coupled to the silk protein). ${ }^{59}$ However, Massia et al. found that fibroblast attachment was higher on an $\alpha 5 \beta 1$ integrin-selective GRGDSP peptide-functionalized surface than on a surface modified with cyclic GpenGRGDSPCA. ${ }^{60}$ In the present study, we compared the effects of KGGRGDSP and c(RGDfK) on HGF biological behaviors. CLSM and CCK-8 assays indicated that $\mathrm{c}(\mathrm{RGDfK})$ promoted slightly better cell adhesion, spreading, and proliferation than did KGGRGDSP. However, gene and protein expression analyses indicated that the linear and cyclic peptides induced Col-1 secretion to comparable levels. These findings could be interpreted as follows: the linear GRGDSP-containing peptide and the c(RGDfK) peptide have similar affinity for $\alpha 5 \beta 1$ integrin, which is critical for fibroblasts to bind and respond to the ECM, whereas the cyclic peptide has higher affinity for other integrins, and the cell behaviors reflect the summation of different binding affinities. Further, cell adhesion depends also on the density of immobilized peptides. ${ }^{61}$ Small changes in peptide density can have dramatic effects in terms of their functions. The two RGD peptides in this study were grafted onto the zirconia surfaces at the same concentration, and their density was neither the same nor constant. As shown in Fig. 2, more punctate green fluorescence was observed on $\mathrm{ZrO}_{2}-\mathrm{P} / \mathrm{C}$ than on $\mathrm{ZrO}_{2}-\mathrm{P} / \mathrm{L}$ surfaces, indicating the higher density of $\mathrm{c}(\mathrm{RGDfK})$. This difference in density may partly explain the differential effects of $\mathrm{ZrO}_{2}-\mathrm{P} / \mathrm{C}$ and $\mathrm{ZrO}_{2}-\mathrm{P} / \mathrm{L}$ on cell activity. In addition, the linear RGD peptide has probably no conformation like the cyclic RGD peptide. The PDAmediated RGD immobilization was carried out in aqueous solutions, the conformation of the peptides was hardly destroyed, thus retaining their receptor-binding capability and biological activity to the most extent.

\subsection{Bacterial responses}

CLSM and SEM images of the colonization of $S$. mutans and $P$. gingivalis on the different substrates are shown in Fig. 8A and B.
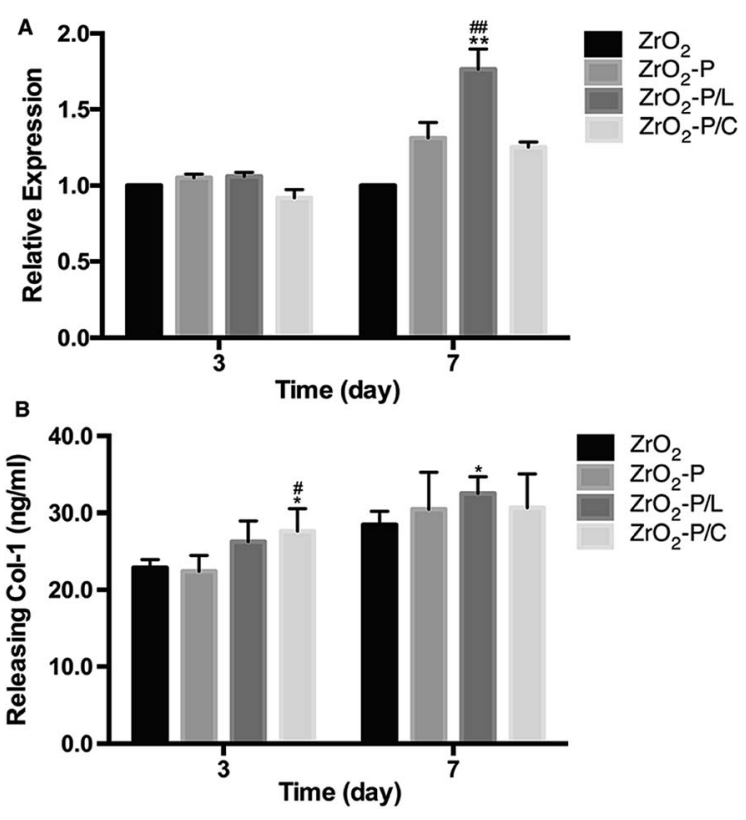

Fig. 7 The expression of Col-1 at gene (A) and protein (B) levels after 3 and 7 days of culture. * represents $p<0.05$ and ** represents $p<0.01$, compared with pristine zirconia. " represents $p<0.05$ and \#\# represents $p<0.01$, compared with $\mathrm{ZrO}_{2}-\mathrm{P}$. 
The adhesion density of $S$. mutans as well as $P$. gingivalis (sum of live and dead cells in CLSM) was decreased on $\mathrm{ZrO}_{2}-\mathrm{P}, \mathrm{ZrO}_{2}-\mathrm{P} / \mathrm{L}$, and $\mathrm{ZrO}_{2}-\mathrm{P} / \mathrm{C}$ as compared with $\mathrm{ZrO}_{2} . \mathrm{ZrO}_{2}-\mathrm{P}, \mathrm{ZrO}_{2}-\mathrm{P} / \mathrm{L}$, and $\mathrm{ZrO}_{2}-\mathrm{P} / \mathrm{C}$ reduced bacterial adhesion to the same extent. CLSM revealed more dead cells of $S$. mutans on $\mathrm{ZrO}_{2}-\mathrm{P}, \mathrm{ZrO}_{2}-\mathrm{P} / \mathrm{L}$ and $\mathrm{ZrO}_{2}-\mathrm{P} / \mathrm{C}$ than on $\mathrm{ZrO}_{2}$. The percentage of bacterial adhesion area to the tested surfaces is shown in Fig. $8 \mathrm{C}$ and D. Consistent with these qualitative microscopic impressions, the area coverages of $S$. mutans on all the modified substrates were significantly lower than on the pristine zirconia surfaces after $3 \mathrm{~h}$ of culture $(p<0.01)$; the differences between experiment groups were not significant. Similar results were found for $P$. gingivalis after incubation for $48 \mathrm{~h}$.

As the oral environment is rich in bacteria, including potential pathogens, the antimicrobial property of dental implants is critical. Early failure of dental implants is often caused by the adhesion of $S$. mutans and other initial colonizers, which prevent the formation of soft tissue seal. ${ }^{62} P$. gingivalis is one of the major pathogens causing peri-implantitis, and plays an important role in regulating biofilm structure and toxicity and subsequent tissue inflammation. ${ }^{63}$ Bacterial infection starts at the implant collars and then spreads along the bone-implant interface, resulting in failure of osseointegration. ${ }^{64}$ Thus, inhibiting bacterial adhesion on the neck portion of the implant at the early stage would be of great significance.

Bacterium-surface adhesion is determined by various surface physicochemical properties, such as roughness, wettability, surface charge, and chemical composition. Surface roughness plays a vital role in bacterial adhesion. As mentioned above, all samples in this study had a surface roughness of approximately $0.2 \mu \mathrm{m}$; therefore, roughness does not explain the differences in bacterial adhesion. Further, hydrophilic materials are more resistant to bacterial adhesion than hydrophobic materials. ${ }^{65}$ In this study, the water contact angle was decreased by $11^{\circ}$ after PDA coating, and by $16^{\circ}$ after RGD functionalization. The enhanced hydrophilicity may account, at least in part, for the decrease in bacterial colonization on modified samples. Surface charge is another crucial physical factor influencing the adherence of microorganisms, e.g., most bacteria are negatively charged and preferentially adhere to positively charged surfaces. The antimicrobial activity of RGD peptides has been rarely explored. ECM proteins such as collagen and $\mathrm{FN}$ contain specific bacterial binding sites; however, few bacteria have been identified to bind directly to sequences containing a single RGD motif. ${ }^{66}$ In a study
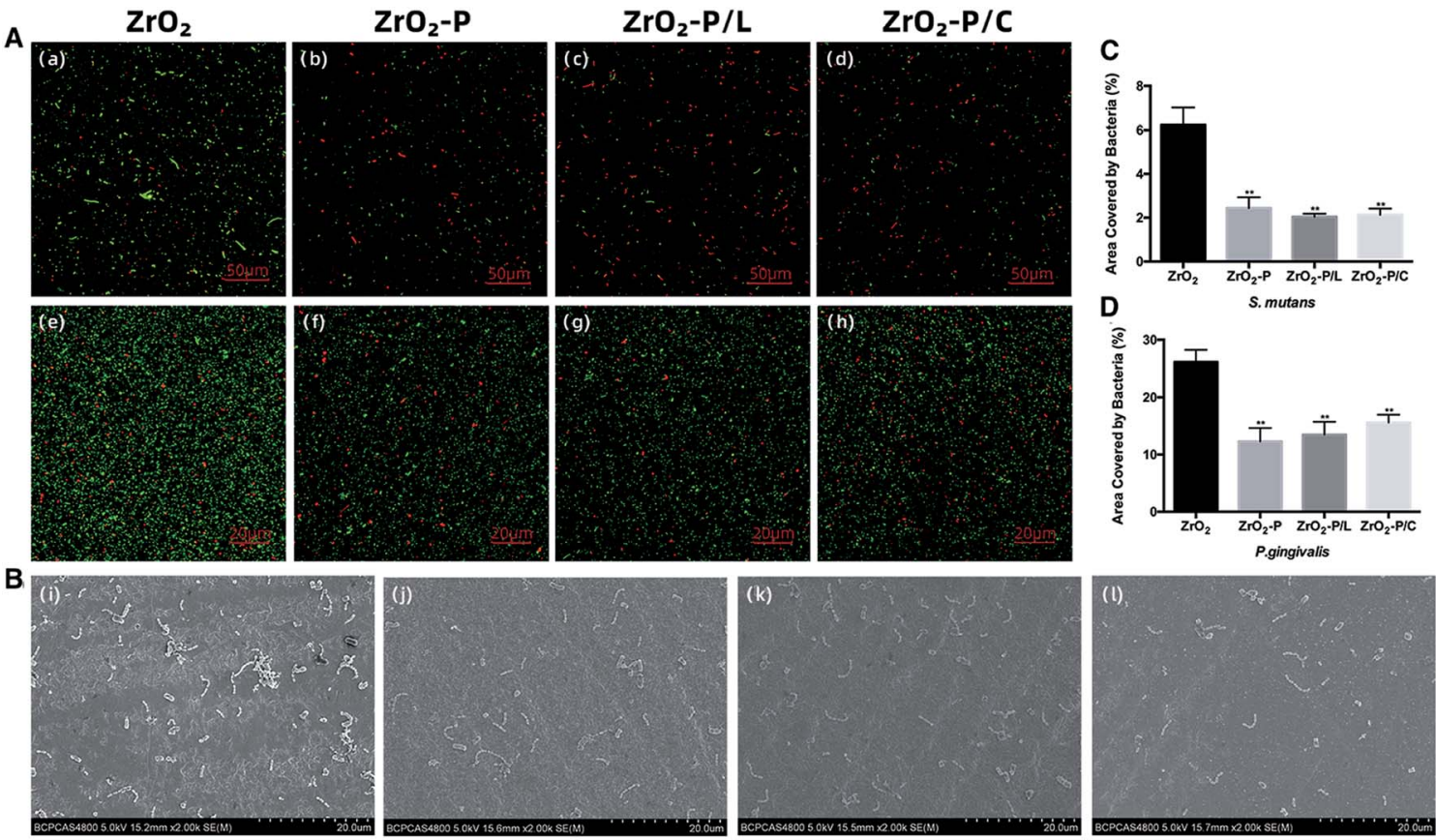

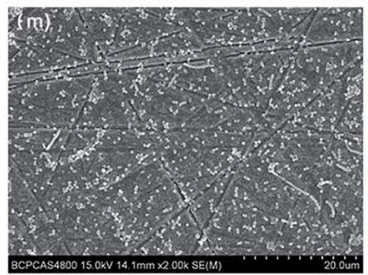

$\mathrm{ZrO}_{2}$

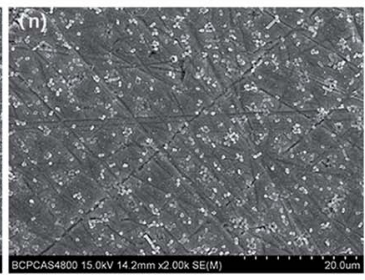

$\mathrm{ZrO}_{2}-\mathrm{P}$

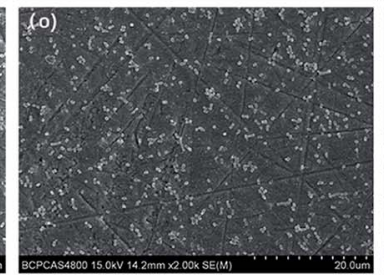

$\mathrm{ZrO}_{2}-\mathrm{P} / \mathrm{L}$
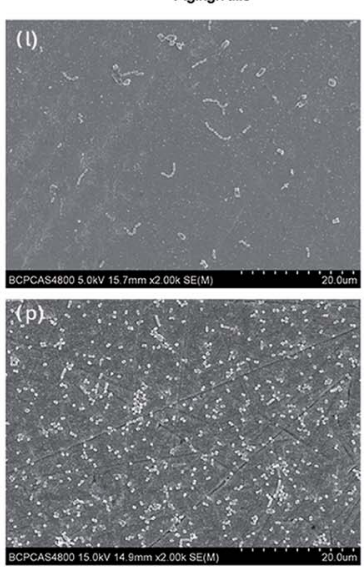

$\mathrm{ZrO}_{2}-\mathrm{P} / \mathrm{C}$

Fig. 8 CLSM (A) images of S. mutans after $3 \mathrm{~h}$ of culture $(A(a-d)$ scale bar $=50 \mu \mathrm{m})$ and $P$. gingivalis after $48 \mathrm{~h}$ of culture $(A(e-h) s c a l e$ bar $=50$ $\mu \mathrm{m})$ on different surfaces. SEM (B) images of $S$. mutans after $3 \mathrm{~h}$ of culture $(B(i-l))$ and $P$. gingivalis after $48 \mathrm{~h}$ of culture $(B(\mathrm{~m}-\mathrm{p}))$ on different surfaces. (C) and (D) Comparison of the area covered by bacteria among unmodified and modified substrates by CLSM images $(n=15)$. $* *$ represents $p<0.01$, compared with pristine zirconia. 
by Chua et al., RGD modification did not affect the antibacterial efficacy of hyaluronic acid/chitosan polyelectrolyte multilayer coating: ${ }^{67}$ Similar findings have been reported in related studies on various bacterial strains. ${ }^{68-70}$ Our findings are consistent with those in previous reports. The extent of bacterial adhesion on PDAmodified surfaces with or without immobilized RGD was significantly lower than that on pristine zirconia, and all modifications were similarly effective in reducing bacterial colonization; thus, the antibacterial effect was presumably largely contributed by PDA. However, results on the antimicrobial activity of PDA coating are controversial. ${ }^{32}$ According to our previous work, PDA coating exerts a bacteriostatic effect on Gram-positive bacteria such as Streptococcus gordonii and $S$. mutans, probably because the negatively charged $(\mathrm{pH}>4)$ and relatively hydrophilic PDA coating reduces the adhesion of negatively charged salivary proteins and subsequently, bacterial adhesion. ${ }^{34}$ Also, Su et al. found that a roughened PDA, prepared by a facile shaking method, exhibited remarkable antibacterial activities against the Gram-positive Staphylococcus aureus, and the Gram-negative Escherichia coli and Pseudomonas aeruginosa. ${ }^{71}$ Their findings suggested that modulation of the physical properties of PDA coating via the preparation conditions might significantly influence its antibacterial activity. The present study demonstrated that the presence of RGD did not influence the antimicrobial properties of PDA film. These findings can be explained as follows. The hydrophilicity was increased after immobilizing RGD peptides onto $\mathrm{ZrO}_{2}-\mathrm{P}$, which would have positively contributed to bacterial adhesion inhibition. However, this effect was likely cancelled out by the fact that RGD has a nearly zero net charge at neutral $\mathrm{pH}$, and therefore, RGD conjugation might have affected the surface charge of the PDA film and thus, decreased its antibacterial activity.

Collectively, our findings indicate that PDA-mediated RGD functionalization greatly improved the early responses of HGFs, such as adhesion and spreading, while reducing the colonization of $S$. mutants and $P$. gingivalis. These results implied that soft tissue-related cells might have a competitive advantage over bacteria in occupying the zirconia abutment surface early after implantation and thus facilitate early soft tissue healing. Furthermore, enhanced HGF proliferation and differentiation on RGD-functionalized zirconia may promote the formation of an extensive and tight connective tissue seal on the transgingival area of the implant. Apart from the efficacy of the coating, long-term stability has to be considered. The PDA and RGD coatings might be degraded in vivo at some point in time by enzymatic activities or under oral physiological forces. However, as the coating is cell-adhesive and bacteria-repellent, HGFs have a considerably greater possibility to win the race-forthe-surface against oral bacteria. Thus, even with a limited lifetime, the coatings are expected to be useful in protecting the implant against bacterial infection in the clinically critical early stage. Nevertheless, further investigations are still needed to assess the longevity of the coatings.

\section{Conclusions}

In the present study, we described a facile and effective surface modification approach for zirconia abutment material, enabling covalently binding of RGD-containing peptides via PDA intermediate layer to significantly improve the biological activity of HGFs. In the comparison between liner and cyclic RGD, cyclic peptides promoted cell attachment, spreading, and proliferation slightly better than linear RGD peptide, whereas both peptides had comparable effects on cell differentiation. Moreover, RGD functionalization did not alter the antibacterial efficacy of PDA coating. Therefore, the zirconia-PDA-RGD surface exhibits selective bio-interactivity, i.e., it is adhesive to soft tissue-forming cells, but repellent to bacteria, a property that holds promise for enhancing peri-implant soft tissue integration. Nevertheless, further studies in vitro and in vivo are necessary to establish the optimal application conditions of PDA-mediated RGD functionalization, and to assess its soft tissue healing-promoting effects in vivo.

\section{Ethical statement}

HGFs were grown from biopsies obtained from a periodontally healthy human subject during periodontal surgery. The process is with the advance approval of informed consent. Meanwhile, the study was approved by the Institutional Review Board of Peking University School of Stomatology (Beijing, China PKUSSIRB-201943032).

\section{Conflicts of interest}

We have no conflicts of interest for the study.

\section{Acknowledgements}

The study was supported by the National Natural Science Foundation of China (No. 81701001) and (No. 81701003).

\section{References}

1 T. Wang, L. Wang, Q. Lu and Z. Fan, J. Prosthet. Dent, 2019, 121, 156-165.

2 F. Al Rezk, G. Trimpou, H. C. Lauer, P. Weigl and N. Krockow, Gen. Dent., 2018, 66, 18-25.

3 A. Sculean, R. Gruber and D. D. Bosshardt, J. Clin. Periodontol., 2014, 41(suppl. 15), S6-S22.

4 A. G. Gristina, Science, 1987, 237, 1588-1595.

5 B. Zhao, H. C. van der Mei, G. Subbiahdoss, J. de Vries, M. Rustema-Abbing, R. Kuijer, H. J. Busscher and Y. Ren, Dent. Mater., 2014, 30, 716-727.

6 M. Rakic, P. Galindo-Moreno, A. Monje, S. Radovanovic, H.-L. Wang, D. Cochran, A. Sculean and L. Canullo, Clin. Oral Invest., 2017, 22, 1805-1816.

7 M. A. Pacha-Olivenza, R. Tejero, M. C. Fernandez-Calderon, E. Anitua, M. Troya and M. L. Gonzalez-Martin, BioMed Res. Int., 2019, 2019, 8456342.

8 B. Li, V. Agarwal, D. Ho, J.-P. Vede and K. S. Iyer, New J. Chem., 2018, 42, 7237-7240.

9 S. Roehling, K. A. Schlegel, H. Woelfler and M. Gahlert, Clin. Oral Implants Res., 2019, 30, 365-395. 
10 L. Treccani, T. Yvonne Klein, F. Meder, K. Pardun and K. Rezwan, Acta Biomater., 2013, 9, 7115-7150.

11 M. Gahlert, T. Gudehus, S. Eichhorn, E. Steinhauser, H. Kniha and W. Erhardt, Clin. Oral Implants Res., 2007, 18, 662-668.

12 Q. Flamant, F. García Marro, J. J. Roa Rovira and M. Anglada, J. Eur. Ceram. Soc., 2016, 36, 121-134.

13 Y. Yang, J. Zhou, X. Liu, M. Zheng, J. Yang and J. Tan, J. Biomed. Mater. Res. B Appl. Biomater., 2015, 103, 116-124.

14 M. Zheng, Y. Yang, X. Q. Liu, M. Y. Liu, X. F. Zhang, X. Wang, H. P. Li and J. G. Tan, PLoS One, 2015, 10, e0140278.

15 Y. Kimie, K. Kae, T. Yusuke, Y. Yuichiro and K. Hirofumi, J. Hard Tissue Biol., 2014, 23, 93-100.

16 Y. Cho, J. Hong, H. Ryoo, D. Kim, J. Park and J. Han, J. Dent. Res., 2015, 94, 491-499.

17 K. Pardun, L. Treccani, E. Volkmann, P. Streckbein, C. Heiss, G. Li Destri, G. Marletta and K. Rezwan, Mater. Sci. Eng., C, 2015, 48, 337-346.

18 U. T. Kalyoncuoglu, B. Yilmaz, S. G. Koc, Z. Evis, P. U. Arpaci and G. Kansu, Clin. Implant Dent. Relat. Res., 2018, 20, 10221029.

19 C. M. Hsu, Y. S. Sun and H. H. Huang, J. Dent. Res., 2019, 98, 556-563.

20 F. Teng, Y. Zheng, G. Wu, B. Beekmans, D. Wismeijer, X. Lin and Y. Liu, Int. J. Periodontics Restor. Dent., 2019, 39, 371379.

21 B. G. Zhang, D. E. Myers, G. G. Wallace, M. Brandt and P. F. Choong, Int. J. Mol. Sci., 2014, 15, 11878-11921.

22 N. Huettner, T. R. Dargaville and A. Forget, Trends Biotechnol., 2018, 36, 372-383.

23 J. W. Park, K. Kurashima, Y. Tustusmi, C. H. An, J. Y. Suh, H. Doi, N. Nomura, K. Noda and T. Hanawa, Acta Biomater., 2011, 7, 3222-3229.

24 H. S. Seo, Y. M. Ko, J. W. Shim, Y. K. Lim, J.-K. Kook, D.-L. Cho and B. H. Kim, Appl. Surf. Sci., 2010, 257, 596-602.

25 G. L. Yang, F. M. He, X. F. Yang, X. X. Wang and S. F. Zhao, Int. J. Periodontics Restor. Dent., 2009, 90, 175-185.

26 J. Michael, L. Schonzart, I. Israel, R. Beutner, D. Scharnweber, H. Worch, U. Hempel and B. Schwenzer, Bioconjugate Chem., 2009, 20, 710-718.

27 Y. Dong, P. Li, C. B. Chen, Z. H. Wang, P. Ma and G. Q. Chen, Biomaterials, 2010, 31, 8921-8930.

28 W. C. Chen and C. L. Ko, Mater. Sci. Eng., C, 2013, 33, 27132722.

29 M. Jager, C. Boge, R. Janissen, D. Rohrbeck, T. Hulsen, S. Lensing-Hohn, R. Krauspe and M. Herten, Int. J. Periodontics Restor. Dent., 2013, 101, 2905-2914.

30 P. Brun, M. Scorzeto, S. Vassanelli, I. Castagliuolo, G. Palu, F. Ghezzo, G. M. Messina, G. Iucci, V. Battaglia, S. Sivolella, A. Bagno, G. Polzonetti, G. Marletta and M. Dettin, Acta Biomater., 2013, 9, 6105-6115.

31 H. Lee, S. M. Dellatore, W. M. Miller and P. B. Messersmith, Science, 2007, 318, 426-430.

32 Y. H. Ding, M. Floren and W. Tan, Biosurf. Biotribol., 2016, 2, 121-136.

33 Y. Liu, K. Ai and L. Lu, Chem. Rev., 2014, 114, 5057-5115.
34 M. Liu, J. Zhou, Y. Yang, M. Zheng, J. Yang and J. Tan, Colloids Surf., B, 2015, 136, 74-83.

35 S. H. Ku, J. Ryu, S. K. Hong, H. Lee and C. B. Park, Biomaterials, 2010, 31, 2535-2541.

36 C. Y. Chien and W. B. Tsai, ACS Appl. Mater. Interfaces, 2013, 5, 6975-6983.

37 C. Y. Chien, T. Y. Liu, W. H. Kuo, M. J. Wang and W. B. Tsai, Int. J. Periodontics Restor. Dent., 2013, 101, 740-747.

38 K. Mustafa, A. Oden, A. Wennerberg, K. Hultenby and K. Arvidson, Biomaterials, 2005, 26, 373-381.

39 B. Chehroudi, T. R. Gould and D. M. Brunette, J. Biomed. Mater. Res., 1990, 24, 1203-1219.

40 M. Quirynen, M. Marechal, H. J. Busscher, A. H. Weerkamp, P. L. Darius and D. van Steenberghe, J. Clin. Periodontol., 1990, 17, 138-144.

41 P. Gehrke, A. Tabellion and C. Fischer, J. Adv. Prosthodont., 2015, 7, 151-159.

42 F. R. Kloss, D. Steinmuller-Nethl, R. G. Stigler, T. Ennemoser, M. Rasse and O. Hachl, Clin. Oral Implants Res., 2011, 22, 699-705.

43 D. Choquet, D. P. Felsenfeld and M. P. Sheetz, Cell, 1997, 88, 39-48.

44 U. Hersel, C. Dahmen and H. Kessler, Biomaterials, 2003, 24, 4385-4415.

45 P. M. Bartold, L. J. Walsh and A. S. Narayanan, Periodontology, 2000, 24, 28-55.

46 R. G. LeBaron and K. A. Athanasiou, Tissue Eng., 2000, 6, 85103.

47 E. Ruoslahti, Annu. Rev. Cell Dev. Biol., 1996, 12, 697-715.

48 S. Yamano, A. K. Ma, R. M. Shanti, S. W. Kim, K. Wada and

C. Sukotjo, Int. J. Oral Maxillofac. Implants, 2011, 26, 12471255.

49 J. Takagi, Biochem. Soc. Trans., 2004, 32, 403-406.

50 N. Faucheux, R. Schweiss, K. Lutzow, C. Werner and T. Groth, Biomaterials, 2004, 25, 2721-2730.

51 W. T. Chen and S. J. Singer, J. Cell Biol., 1982, 95, 205-222.

52 D. S. Wong, J. Li, X. Yan, B. Wang, R. Li, L. Zhang and L. Bian, Nano Lett., 2017, 17, 1685-1695.

53 V. Rutkunas, V. Bukelskiene, V. Sabaliauskas, E. Balciunas, M. Malinauskas and D. Baltriukiene, J. Mater. Sci. Mater. Med., 2015, 26, 169.

54 J. D. Humphries, P. Wang, C. Streuli, B. Geiger, M. J. Humphries and C. Ballestrem, J. Cell Biol., 2007, 179, 1043-1057.

55 A. A. Palaiologou, R. A. Yukna, R. Moses and T. E. Lallier, J. Periodontol., 2001, 72, 798-807.

56 Y. Qian, X. Zhao, Q. Han, W. Chen, H. Li and W. Yuan, Nat. Commun., 2018, 9, 323.

57 S. J. Bogdanowich-Knipp, S. Chakrabarti, T. D. Williams, R. K. Dillman and T. J. Siahaan, J. Pept. Res., 1999, 53, 530541.

58 M. Kato and M. Mrksich, Biochemistry, 2004, 43, 2699-2707. 59 S. Wohlrab, S. Muller, A. Schmidt, S. Neubauer, H. Kessler, A. Leal-Egana and T. Scheibel, Biomaterials, 2012, 33, 6650-6659.

60 S. P. Massia and J. Stark, J. Biomed. Mater. Res., 2001, 56, 390399. 
61 B. T. Houseman and M. Mrksich, Biomaterials, 2001, 22, 943-955.

62 M. C. Cortizo, T. G. Oberti, M. S. Cortizo, A. M. Cortizo and M. A. Fernandez Lorenzo de Mele, J. Dent., 2012, 40, 329-337.

63 Z. Cai, Y. Li, Y. Wang, S. Chen, S. Jiang, H. Ge, L. Lei and X. Huang, Photochem. Photobiol., 2019, 95, 839-845.

64 R. Xing, I. L. Witso, D. Jugowiec, H. Tiainen, M. Shabestari, S. P. Lyngstadaas, J. Lonn-Stensrud and H. J. Haugen, Biomed. Mater., 2015, 10, 055003.

65 T. G. van Kooten, J. M. Schakenraad, H. C. van der Mei and H. J. Busscher, Biomaterials, 1992, 13, 897-904.

66 V. E. Wagner and J. D. Bryers, Int. J. Periodontics Restor. Dent., 2004, 69, 79-90.
67 P. H. Chua, K. G. Neoh, E. T. Kang and W. Wang, Biomaterials, 2008, 29, 1412-1421.

68 T. He, Z. L. Shi, N. Fang, K. G. Neoh, E. T. Kang and V. Chan, Biomaterials, 2009, 30, 317-326.

69 L. G. Harris, S. Tosatti, M. Wieland, M. Textor and R. G. Richards, Biomaterials, 2004, 25, 4135-4148.

70 J. Buxadera-Palomero, C. Calvo, S. Torrent-Camarero, F. J. Gil, C. Mas-Moruno, C. Canal and D. Rodriguez, Colloids Surf., B, 2017, 152, 367-375.

71 L. Su, Y. Yu, Y. Zhao, F. Liang and X. Zhang, Sci. Rep., 2016, 6, 24420. 